\title{
EFFECT OF PULSING WITH VARIOUS PRESERVATIVES ON POSTHARVEST PERFORMANCE OF CUT Polianthes tuberosa L. 'SINGLE' SPIKES
}

\author{
Muhammad Asif $^{1, *}$, Iftikhar Ahmad ${ }^{1}$, M. Qasim ${ }^{1}$ and Rashid Ahmad ${ }^{2}$ \\ ${ }^{1}$ Institute of Horticultural Sciences, University of Agriculture, Faisalabad, Pakistan. \\ ${ }^{2}$ Department of Agronomy, University of Agriculture, Faisalabad, Pakistan. \\ *Corresponding author's e-mail: roymasif@yahoo.co.in
}

\begin{abstract}
In Punjab-Pakistan, growing tuberose is a profitable business as returns are double than cost despite of certain bottlenecks such as fluctuations in the prices and unawareness of farmers regarding its post-harvest handling. Keeping in view high market demand in local flower markets, the present study was conducted to extend the postharvest life of cut tuberose spikes by pulsing cut spikes with various preservatives. Among various pulsing treatments, $10 \%$ sucrose plus $50 \mathrm{mg} \mathrm{L}^{-1}$ salicylic acid (SA) for 24 hours proved best with the longest vase life ( $10.2 \mathrm{~d}$ ), more number of days required to open $50 \%$ florets (5.0 days), maximum dry weight percentage (13.2\%) and superior quality spikes (7.6). Moreover, longest florets $(7.0 \mathrm{~cm})$ with greater floret diameter $(4.2 \mathrm{~cm})$, highest percentage of opened florets $(90.0 \%)$ and minimum ion leakage of florets $(140.0 \%)$ was recorded for spikes pulsed with $10 \%$ sucrose plus $50 \mathrm{mg} \mathrm{L}^{-1}$ salicylic acid for 24 hours. On the other hand, highest water uptake $(106.0 \mathrm{~mL})$ and the maximum relative fresh weight percentage $(109.9 \%)$ were observed in cut tuberose spikes treated with $50 \mathrm{mg} \mathrm{L}^{-1} \mathrm{salicylic}$ acid without sucrose solution. In summary, pulsing of cut tuberose spikes with $50 \mathrm{mg} \mathrm{L}^{-1} \mathrm{SA}$ with or without $10 \%$ sucrose proved effective for extending vase life and improving postharvest performance of cut tuberose spikes.
\end{abstract}

Keywords: Ascorbic acid, floriculture, relative fresh weight, salicylic acid, sucrose, vase life

\section{INTRODUCTION}

Tuberose (Polianthes tuberosa L.) is native to Mexico and a member of family Amaryllidaceae. Tuberose spikes have 1020 pairs of florets, which open from base to upwards and make excellent cut flowers and are popular for their fragrance (De Hertogh and Le Nord, 1993). Moreover, its flowers are also used to extract essential oil, which is used for the production of cosmetic and perfumery products (Hussain, 1986). It is very popular cut flower in Punjab-Pakistan and in fact is the only major cut flower available in the florist shops during summer and very much appreciated by the consumers for its fragrance (Ahsan et al., 2012; Ashfaq et al., 2015).

In Punjab-Pakistan, growing tuberose is a profitable business as returns are double than cost (Usman and Ashfaq, 2013) despite certain bottlenecks such as fluctuations in the prices and unawareness of farmers regarding its post-harvest handling. Previous studies have demonstrated that cut flower growers in Pakistan are generally unaware of modern postharvest handling of cut flowers (Ahmad, 2009). Their packaging and transportation practices are not up to the standard, which result in poor quality produce in the market with shorter vase life. All this results in to heavy postharvest losses, which may range between 10-30\% (Hayat et al., 2012) and sometimes up to 40 percent in the absence of floral preservatives (Hutchinson et al., 2003). Tuberose is heat loving plant and can successfully be grown with little care, which makes it the only choice for the cut flower growers during summer season in Punjab, Pakistan. Therefore, more often local florist markets become glutted with it during peak production time, which results in price drop and ultimately cause economic losses to the growers.

Pulsing with sucrose applied before storage or shipping increased the postharvest longevity of many cut flowers, probably by replacing the carbohydrates during cold storage (van Doorn et al., 1991; Khan et al., 2015), or preventing leaf desiccation (Silvanda et al., 2011). Sucrose (1-5\%) have significant effect on quality parameters, viz. vase life, flower quality, water uptake, leaf chlorophyll contants, fresh and dry weight of cut rose flowers and can maintain the vase life of flowers for a longer period (Younis et al., 2006; Mirjalili, 2015). Similarly, pulsing of cut tuberose flower with $10 \%$ sucrose before transfer to deionized water improved vase life by 4 days and improved floret opening by $21 \%$ relative to control probably by improving water balance (Hutchinson $e t$ al., 2003). However, sucrose alone cannot be used without germicides, as sucrose promotes bacterial proliferation leading to shortening of vase life (Ichimura et al., 2002).

Pulse treatment of freesia flowers, with $20 \%$ sucrose for $24 \mathrm{~h}$ prior to three days of simulated shipping, improved subsequent vase life (Woodson, 1987). Abdulrahman et al. (2012) reported that $0.5 \mathrm{~g} \mathrm{~L}^{-1}$ of sucrose significantly increased time to stem bending, fresh and dry weight, percentage change in fresh weight and total carbohydrates, 
and vase life of snapdragon cut flower. Kim and Lee (2002) suggested pulsing snapdragon flowers in sucrose vases resulted in higher longevity period, which indicated that sucrose played a critical role in promoting water absorption and metabolic processes within the flower.

Salicylic acid (SA) is a natural, cheap, safe, and biodegradable compounds which is suitable alternative for conventional chemical treatments in order to prolong vase life of cut rose flowers (Abdolmaleki, 2015). It is a signaling molecule which regulates plant growth and development together with local and endemic disease resistance in plants in response to various pathogenic attacks and environmental stresses. Moreover, SA interferes with the biosynthesis and/or action of ethylene, abscisic acid and cytokinins in plants (Hayat et al., 2010). SA treatments extended vase life in association with inhibition of ethylene production (Leslie and Romani, 1988). In free state, $\mathrm{SA}$ has a $\mathrm{pH}$ of 2.4 and acidic solution inhibits bacteria growth and proliferation (Enyedi et al., 1992). However, SA can modulate plant responses to a wide range of oxidative stresses and prevents cell wall degradation and thereby reduction in water loss (Shirasu et al., 1997). Moreover, addition of $300 \mathrm{ppm}$ salicylic acid to distilled water extended the vase life of Alstroemeria peruviana, Gerbera jamesonii, Lilium asiaticum, Polianthes tuberosa and Rosa hybrida by $30-55 \%$ relative to control. Besides, SA treatments increased relative water content, petal water content and initial fresh weight in cut flowers, over control. The beneficial effects of salicylic acid are associated with the plant regulating and anti-stress properties of salicylic acid. Researchers strongly suggest SA as a vase solution additive being natural, cheap, safe and biodegradable compound for extending the postharvest longevity of cut flower species susceptible to vascular blockage of bacteria and ethylene (Tehranifar et al., 2013). SA, a vase solution additive for extending the postharvest longevity of flower species, susceptible to vascular blockage of bacteria and ethylene, helps maintaining relative water constants (RWC). It was observed that SA (100-300 ppm) treated plants showed $50 \%$ higher RWC compared to control which extended the postharvest life of cut flowers (Tehranifar et al., 2013). Moreover, SA treatment at $1.5 \mathrm{mM}$ showed the best effect on fresh weight, water uptake and vase life of cut flowers (Marandi et al., 2011). Kazemi et al. (2011) elaborated that SA treatment decreased microbial population and increased water uptake in carnation cut flowers.

Ascorbic acid (AsA) (vitamin C), a novel enzyme, is a product of D-glucose metabolism in higher plants. It affects plant growth and development and plays a role in electron transport system (El-Kobisy et al., 2012). Ascorbic acid has been associated with several types of biological activities in plants. For instance, as enzyme co-factors, antioxidant, and as a donor/acceptor in electron transport at the plasma membrane or in the chloroplast (Conklin, 2001). Moreover, a high level of endogenous ascorbic acid is necessary to maintain the antioxidant system that protects plants from oxidative damage (Cheruth, 2009). Azizi et al. (2015) investigated various but continuous treatments of ascorbic acid, viz. 0, 50, 100 and 200 $\mathrm{mg} \mathrm{L}^{-1}$ to lisianthus cut flowers and reported that longest vase life, maximum solution uptake, highest dry matter and minimum loss of fresh weight were obtained $200 \mathrm{mg} \mathrm{L}^{-1}$ ascorbic acid. Moreover, they concluded that ascorbic acid, as a natural antioxidant which helped prolonging keeping quality of cut lisianthus flowers when applied at suitable concentration.

Abdulrahman et al. (2012) investigated various levels of ascorbic acid (50, 100, $\left.150 \mathrm{mg} \mathrm{L}^{-1}\right)$ and suggested that $150 \mathrm{mg}$ $\mathrm{L}^{-1}$ (AsA) significantly increased vase life, fresh weight and percentage of total carbohydrates in cut snapdragon flowers. Moreover, ascorbic acid at 200 ppm improved growth and keeping quality by delaying flower opening and stimulating accumulation of carbohydrate, probably due to a fact that vitamins like ascorbic acid are considered as a bio-regulator compounds, which in little concentration exerted profound influence upon quality and long vase life (Bedour and Rawia, 2011). Sheikh et al. (2014) suggested ascorbic acid as cheap, safe, biodegradable compound and suitable alternative for chemical treatments in order to prolong vase life of cut flowers of Eustoma as it exhibited the longest vase life and heigher relative water contents and petal water contents at 300 $\mathrm{mg} \mathrm{L}^{-1}$ ascorbic acid due to its acidic and anti-stress properties.

Keeping in view high market demand in local flower markets and role of pulsing with various chemicals to improve the postharvest life of cut flowers, present study was conducted with an aim to extend the postharvest life of cut tuberose spikes.

\section{MATERIALS AND METHODS}

Plant material: Cut spikes were obtained from a commercial grower at Pattoki, Distt. Kasur, Punjab. Flowers grown in open field were harvested early in the morning before 10:00 A.M., packed in cardboard boxes and immediately transported in air-conditioned vehicle to Postharvest and Floriculture Laboratory, Institute of Horticultural Sciences, University of Agriculture, Faisalabad, Pakistan, within 5 hours of harvest.

Spikes handling in laboratory: On arrival, flowers were recut to $60 \mathrm{~cm}$ length for the removal of any air embolism. Except upper two, all leaves were removed from lower side of spikes and placed in separate jars according to the treatments having $500 \mathrm{~mL}$ of pulsing solution for 24 hours at room temperature. Afterwards, spikes were placed in jars with three spikes each according to the treatments having $500 \mathrm{~mL}$ of distilled water, in a vase life evaluation room. Vases (glass jars) were arranged in a vase life evaluation room at $23 \pm 2{ }^{\circ} \mathrm{C}$ temperature, $60 \pm 10 \%$ R.H. and a photosynthetically active photon flux of $12 \mu \mathrm{mol} \mathrm{m} \mathrm{m}^{-2} \mathrm{~s}^{-1}$ with $12 \mathrm{~h}$ photoperiod from cool 
white florescent tubes. Experiment was arranged in a completely randomized design with five replications in each treatment having three cut spikes in each experimental unit (glass jar).

Pulsing treatments: The concentrations of chemicals were selected on the basis of preliminary experiments (data not shown). There were seven treatments and a control, viz. $10 \%$ sucrose, $50 \mathrm{mg} \mathrm{L}^{-1}$ salicylic acid, $100 \mathrm{mg} \mathrm{L}^{-1}$ acetyl salicylic acid, $100 \mathrm{mg} \mathrm{L}^{-1}$ ascorbic acid, $10 \%$ sucrose plus $50 \mathrm{mg} \mathrm{L}^{-1}$ salicylic acid, $10 \%$ sucrose plus $100 \mathrm{mg} \mathrm{L}^{-1}$ acetyl salicylic acid and $10 \%$ sucrose plus $100 \mathrm{mg} \mathrm{L}^{-1}$ ascorbic acid.

Data regarding following postharvest indices were recorded using standard procedures:

\section{Spike Characteristics:}

Vase life (days): Stems were observed daily for visual appeal. Vase life was considered ended if, either half of the florets were wilted or bent neck symptoms appeared or the visual quality of the spike did not meet the commercial standards (Joyce et al., 2000; Ahmad et al., 2011).

Water uptake $(\boldsymbol{m L})$ : Volume of water absorbed during first five days of vase life was measured by recording remaining volume of vase water on day 5 of vase life from each jar containing three spikes. Water uptake was calculated as:

$$
\text { Water uptake }(\mathrm{mL})=\left(\mathrm{S}_{0}-\mathrm{S}_{5}\right)
$$

Where, $S_{0}$ is the amount of vase water on day 0 and $S_{5}$ is the amount of vase water on the day 5 (Kazemi and Ameri, 2012). Relative fresh weight (\% of initial $F W$ ): Relative fresh weight (RFW) on day 5 of vase life (Kazemi and Ameri, 2012) was calculated as:

Relative fresh weight of spike $(\mathrm{RFW})=\left(\mathrm{FW}_{5} / \mathrm{FW}_{0}\right) \times 100$ Where FW5 is the fresh weight ( $\mathrm{g}$ ) of stem on day 5 and FW0 is the fresh weight $(\mathrm{g})$ of the same stem on day 0 (He et al., 2006; Ahmad et al., 2011). Relative fresh weight of one spike was measured from each replication and average was worked out.

Days to open 50\% florets (days): Number of days was counted starting from the day 0 to the day when $50 \%$ of the total florets were completely opened on the spike.

Dry weight (\%): Dry weight percentage was calculated by using following formula:

$$
\text { Dry weight } \% \text { age }=(\mathrm{DW} / \mathrm{FW}) \times 100
$$

Dry weight of same spike was measured whose fresh weight was measured earlier on day 0 from each replication and averaged. For estimation of dry weight, cut spikes were sun dried for one day, packed in brown paper bags and kept in oven at $80^{\circ} \mathrm{C}$ for 48 hours to record the dry weight at the end of vase life (Ahmad, 2009). Dry weight percentage of one spike was measured from each replication and average was worked out.

Spike/flower quality: Flower quality was rated by three different judges (postgraduate floriculture students) adopting the method described by Dest and Guillard (1987) and average was worked out. Flower quality was rated in numbers using a scale ranging from 1 to 9 , where $1=$ Poor quality, $5=$ Medium quality, $9=$ Good quality.

Spike quality was judged when $50 \%$ of florets were opened on spikes.

Floret Characteristics:

Average life of floret (hours): It was calculated by counting the numbers of hours starting from the opening of bud till floret lose its freshness. It was calculated from two florets of each spike in each replication and average was computed.

Floret head diameter $(\mathbf{c m})$ : Head diameter of fully opened two uppermost florets from each spike in each replication was measured on the last day of vase life with digital caliper and then their average was computed.

Floret length $(\mathbf{c m})$ : Length of two fully opened uppermost florets from each spike in each replication was measured on the last day of vase life with a measuring scale and average was worked out.

Open floret (\%): Total number of florets (opened and closed) was counted on last day of vase life and number of opened florets was calculated as:

Open florets $(\%$ age $)=($ florets opened/ total florets $) \times 100$ Open florets percentage was computed from 15 spikes per treatment and average was worked out.

Ion leakage of floret (\%): Ion leakage of florets was measured on the last day of vase life of each treatment. For this purpose, five fresh florets were randomly selected from each replication and rubbed with silica powder. Rubbed petals were washed thoroughly with distilled water and shifted to test tubes containing $15 \mathrm{~mL}$ distilled water. These test tubes were placed on an orbital shaker for $10 \mathrm{~min}$ and $\mathrm{EC}_{1}$ was recorded. Again test tubes were placed on the orbital shaker for another $100 \mathrm{~min}$. and $\mathrm{EC}_{2}$ was recorded (Ahmad, 2009) and ion leakage was calculated by using following equation:

$$
\text { Ion leakage }(\%)=\frac{\mathrm{EC}_{2}}{\mathrm{EC}_{1}} \times 100
$$

Change in pH and $\boldsymbol{E C}\left(\boldsymbol{d S} \boldsymbol{m}^{-1}\right)$ : Initial and final $\mathrm{pH}$ and $\mathrm{EC}$ of vase water were recorded using $\mathrm{pH}$ and EC meter (HannaHI9813-6) to observe changes in $\mathrm{pH}$ and EC during the study. For this purpose, three readings were taken from each replication on day 0 and final day of vase life of each cut spike and average was worked out.

Change in total soluble solids $\left({ }^{\circ}\right.$ Brix) of florets: Total soluble solids of florets were measured on day 0 and at the end of vase life. For this purpose, six fully open florets were squashed to obtain sap from each replication. TSS in the sap was measured with the hand refractometer with a range of 0 to $30{ }^{\circ}$ Brix by placing one drop on the prism as described by Bayleyegn et al. (2012). Between samples, prism of refractometer was washed with alcohol, rinsed by distilled water and dried using tissue paper. Three readings were taken from each replication and then their average was computed.

Statistical analysis: Experiment was arranged in a completely randomized design and data were analyzed using General 
Linear Model (GLM) procedures of the Statistix 8.1. Means were separated using Least Significant Difference test (LSD) at $P \leq 0.05$ (Steel et al., 1997).

\section{RESULTS}

\section{Spike Characteristics:}

Vase life (days): Data revealed highly significant differences $(\mathrm{P} \leq 0.0001)$ among various pulsing treatments for vase life (Table 1). Longest vase life (10.2 d) was recorded in spikes pulsed with combination of $10 \%$ sucrose plus $50 \mathrm{mg} \mathrm{L}^{-1}$ salicylic acid for 24 hours followed by spikes pulsed with 50 $\mathrm{mg} \mathrm{L}^{-1}$ salicylic acid (9.2 d). Pulsing with $10 \%$ sucrose plus $50 \mathrm{mg} \mathrm{L}^{-1}$ salicylic acid extended vase life by 3.6 days compared to spikes pulsed in control (distilled water). All the pulsing treatments increased the vase life of spikes, compared to distilled water which had shorter vase life (6.6 days).

Water uptake ( $m L)$ : Highly significant differences $(\mathrm{P} \leq 0.0001)$ among various pulsing treatments for water uptake on day five of vase life was observed (Table 1). Highest water uptake $(106.0 \mathrm{~mL})$ was observed for spikes pulsed with $50 \mathrm{mg} \mathrm{L}^{-1}$ salicylic acid, which was at par with water absorbed by the spikes pulsed with $10 \%$ sucrose (104.0 $\mathrm{mL}$ ) or $10 \%$ sucrose plus $50 \mathrm{mg} \mathrm{L}^{-1}$ salicylic acid (101.6 mL). Moreover, water uptake of spikes pulsed with $50 \mathrm{mg} \mathrm{L}^{-1}$ salicylic acid was $26 \mathrm{~mL}$ greater than water taken up by the spikes in control $(84.0 \mathrm{~mL})$, which absorbed minimum water. Relative fresh weight (\% of initial $F W$ ): Data depicted significant differences $(\mathrm{P}=0.0274)$ among various pulsing treatments for relative fresh weight percentage of spikes on day five of vase life (Table 1). The spikes pulsed with $50 \mathrm{mg}$ $\mathrm{L}^{-1}$ salicylic acid exhibited the maximum relative fresh weight percentage $(109.9 \%)$ followed by combination of $10 \%$ sucrose plus $50 \mathrm{mg} \mathrm{L}^{-1}$ salicylic acid (108.4\%), $100 \mathrm{mg} \mathrm{L}^{-1}$ acetyl salicylic acid (107.7\%), $100 \mathrm{mg} \mathrm{L}^{-1}$ ascorbic acid $(107.5 \%)$ and $10 \%$ sucrose $(110.7 \%)$. However, relative fresh weight percentages of all these treatments were statistically similar to each other but greater than other treatments. On the other hand, spikes without pulsing (control) had minimum relative fresh weight percentage (104.6\%).

Days to open 50\% florets (days): Significant differences existed $(\mathrm{P}=0.0115)$ among various pulsing treatments for days to open $50 \%$ florets on spikes (Table 1). The spikes pulsed with $10 \%$ sucrose plus $50 \mathrm{mg} \mathrm{L}^{-1}$ salicylic acid took significantly longer time to open $50 \%$ florets (5.0 days) and prolonged the time period to open $50 \%$ florets on spikes by 1.6 days as compared to control, followed by spikes pulsed with $50 \mathrm{mg} \mathrm{L}^{-1}$ salicylic acid (4.6 days) and $10 \%$ sucrose plus $100 \mathrm{mg} \mathrm{L}^{-1}$ ascorbic acid (4.4 days). However, these differences were non-significant among each other. On the other hand, spikes without pulsing (distilled water) took minimum number of days (3.4) to open $50 \%$ florets.

Dry weight (\%): Highly significant differences $(\mathrm{P}<0.0001)$ among various pulsing treatments were recorded for dry weight percentage of spikes (Table 1). Dry weight percentage $(13.2 \%)$ observed in spikes pulsed with $10 \%$ sucrose plus 50 $\mathrm{mg} \mathrm{L}^{-1}$ salicylic acid, $10 \%$ sucrose $(13 \%), 10 \%$ sucrose plus $100 \mathrm{mg} \mathrm{L}^{-1}$ acetyl salicylic acid (12.8\%) and $10 \%$ sucrose plus $100 \mathrm{mg} \mathrm{L}^{-1}$ ascorbic acid (12.7\%) was statistically similar but greater than the rest of treatments. Minimum dry weight percentage $(10.7 \%)$ was recorded in control which was $2.5 \%$ less than spikes pulsed with $10 \%$ sucrose plus $50 \mathrm{mg} \mathrm{L}^{-1}$ salicylic acid.

Spike quality: Highly significant differences $(\mathrm{P}=0.0002)$ in the spike quality were observed among various pulsing treatments (Table 1). Significantly superior quality spikes (7.6) were observed when pulsed with $10 \%$ sucrose plus 50 $\mathrm{mg} \mathrm{L} \mathrm{L}^{-1}$ salicylic acid followed by spikes pulsed with $50 \mathrm{mg}$

Table 1. Effect of pulsing with different preservatives on spike characteristics of tuberose.

\begin{tabular}{|c|c|c|c|c|c|c|}
\hline Treatments & $\begin{array}{c}* \text { Vase life } \\
\text { (days) }\end{array}$ & $\begin{array}{c}\text { *Water } \\
\text { uptake } \\
(\mathrm{mL})\end{array}$ & $\begin{array}{c}* * \text { Relative } \\
\text { fresh weight } \\
(\%)^{z}\end{array}$ & $\begin{array}{c}\text { *Days to } \\
\text { open 50\% } \\
\text { Florets } \\
\end{array}$ & $\begin{array}{c}* * \text { Dry } \\
\text { weight }(\%)^{y}\end{array}$ & $\begin{array}{l}\text { *Spike } \\
\text { quality }\end{array}$ \\
\hline & & $87.6 \pm 1.6 \mathrm{~b}$ & $104.6 \pm 0.6 \mathrm{~b}$ & & & \\
\hline & & & & & & $2 b c$ \\
\hline & & $2 \mathrm{a}$ & 109 & 4.6 & & \\
\hline $\operatorname{sid}(\triangle \mathrm{S} \triangle)$ & $8.0 \pm 0$ & $84.0 \pm 2.2 \mathrm{~b}$ & $107.7 \pm$ & $4.0 \pm$ & $10.4 \pm$ & $.24 \mathrm{~cd}$ \\
\hline $100 \mathrm{n}$ & $8.2 \pm 0$. & $90.8 \pm 2.7 \mathrm{~b}$ & $107.5 \pm$ & $4.2 \pm$ & $10.4 \pm$ & $.24 \mathrm{bc}$ \\
\hline $10 \%$ & $10.2 \pm 0.37 \mathrm{a}$ & $101.6 \pm 3.3 \mathrm{a}$ & $108.4 \pm 2.4 \mathrm{ab}$ & $5.0 \pm 0$ & $13.2 \pm 0$ & $7.6 \pm 0.24 \mathrm{a}$ \\
\hline & $8.6 \pm 0.6 \mathrm{bc}$ & $88.8 \pm 4.3 \mathrm{~b}$ & $105.2 \pm 0.3 \mathrm{~b}$ & $4.2 \pm 0.2$ & $12.8 \pm 0$ & $6.2 \pm 0.37 \mathrm{bc}$ \\
\hline ose+100 mg L L AA & $8.6 \pm 0.4 b c$ & $89.4 \pm 3.8 \mathrm{~b}$ & $105.1 \pm 0.4 \mathrm{~b}$ & $4.4 \pm 0.2 \mathrm{ab}$ & $12.7 \pm 0.2 \mathrm{a}$ & $6.4 \pm 0.24 b c$ \\
\hline & & $<0.0001$ & & 0.0115 & $<0.0001$ & 0.0002 \\
\hline
\end{tabular}

${ }^{\mathrm{z}}$ Relative fresh weight of spike $(\mathrm{RFW})=\left(\mathrm{FW}_{5} / \mathrm{FW}_{0}\right) \times 100$, where $\mathrm{FW}_{5}$ : Fresh weight at day 5 and $\mathrm{FW}_{0}$ : Fresh weight at day $0 .{ }^{\mathrm{y}}$ Dry weight $\%$ age $=(\mathrm{DW} / \mathrm{FW}) \times 100$, where FW: Fresh weight at day 0 and DW: Dry weight at the end of vase life. ${ }^{\mathrm{x}}$ Means separation within columns by Least significant difference test at $\mathrm{P} \leq 0.05$. ${ }^{\text {w }} \mathrm{P}$ values were obtained using General Linear Model (GLM) procedures of Statistix 8.1. ${ }^{*}$ Values are averages of 15 replicate spikes. ${ }^{* *}$ Values are averages of 5 replicate spikes. 
Table 3. Change in pH and EC of vase water, while total soluble solids (TSS) in florets during vase life. Values are averages of 15 readings.

\begin{tabular}{|c|c|c|c|c|c|c|c|c|c|}
\hline Treatments & $\begin{array}{c}\text { Initial } \\
\text { pH }\end{array}$ & $\begin{array}{c}\text { Final } \\
\text { pH }\end{array}$ & \begin{tabular}{|c|} 
pH \\
change
\end{tabular} & $\begin{array}{c}\text { Initial EC } \\
\left(\mathrm{dS} \mathrm{m}^{-1}\right)\end{array}$ & $\begin{array}{c}\text { Final EC } \\
\left(\mathbf{d S ~ m}^{-1}\right)\end{array}$ & \begin{tabular}{|c|} 
EC \\
change
\end{tabular} & \begin{tabular}{|c|} 
Initial \\
TSS \\
\end{tabular} & \begin{tabular}{|c|} 
Final \\
TSS \\
\end{tabular} & \begin{tabular}{|c|} 
TSS \\
Change
\end{tabular} \\
\hline Control ( Distilled water) & 6.9 & 7.1 & +0.2 & 0.65 & 0.57 & -0.08 & 6.8 & 6.0 & -0.8 \\
\hline $10 \% s$ & 6.2 & 6.3 & +0.1 & 0.57 & 0.50 & -0.07 & 7.1 & 7.5 & +0.4 \\
\hline $\mathrm{L}^{-1}$ salicylic acid $(\mathrm{SA})$ & 4.6 & 4.9 & +0.2 & 0.74 & 0.81 & +0.07 & 6.5 & 6.3 & -0.2 \\
\hline $100 \mathrm{mg} \mathrm{L}^{-1}$ acetyl salicylic acid (AsA) & 4.3 & 4.4 & +0.1 & 0.25 & 0.24 & -0.01 & 6.0 & 5.6 & -0.4 \\
\hline $100 \mathrm{mg} \mathrm{L}^{-1}$ ascorbic acid (AA) & 5.2 & 4.6 & -0.6 & 0.88 & 0.66 & -0.22 & 6.0 & 5.5 & -0.5 \\
\hline $10 \%$ sucrose $+50 \mathrm{mg} \mathrm{L}^{-1} \mathrm{SA}$ & 5.5 & 5.4 & -0.1 & 0.89 & 0.19 & -0.70 & 6.9 & 6.9 & 0.0 \\
\hline $10 \%$ sucrose $+100 \mathrm{mg} \mathrm{L}^{-1} \mathrm{AsA}$ & 4.3 & 4.4 & +0.1 & 0.25 & 0.24 & -0.01 & 5.6 & 5.8 & +0.2 \\
\hline $10 \%$ sucrose $+100 \mathrm{mg} \mathrm{L}^{-1} \mathrm{AA}$ & 4.5 & 4.5 & 0.0 & 0.91 & 0.11 & -0.79 & 6.6 & 6.8 & +0.2 \\
\hline
\end{tabular}

$\mathrm{L}^{-1}$ salicylic acid (6.8). Inferior spike quality was observed in control (distilled water) (5.2).

Florets Characteristics:

Floret length $(\mathbf{c m})$ : Highly significant differences were
(90.0\%) of opened florets was recorded in the spikes pulsed with $10 \%$ sucrose plus $50 \mathrm{mg} \mathrm{L}^{-1}$ salicylic acid than all other treatments but at par with the percentage noted in spikes pulsed with $50 \mathrm{mg} \mathrm{L}^{-1}$ salicylic acid (88.4\%). More florets

Table 2. Effect of pulsing with different preservatives on floret characteristics of tuberose.

\begin{tabular}{|c|c|c|c|c|}
\hline Treatments & *Length (cm) & "Diameter(cm) & *Open florets $(\%)^{\mathrm{z}}$ & ${ }^{* * *}$ Ion leakage $(\%)^{y}$ \\
\hline Control ( Distilled water) & $6.1 \pm 0.12 \mathrm{~d}^{\mathrm{x}}$ & $3.8 \pm 0.06$ & $70.0 \pm 1.8 \mathrm{~d}$ & $175.8 \pm 2.4 \mathrm{a}$ \\
\hline $10 \%$ Sucrose & $6.4 \pm 0.09 \mathrm{c}$ & $4.2 \pm 0.15$ & $84.0 \pm 2.2 \mathrm{bc}$ & $171.8 \pm 2.4 \mathrm{a}$ \\
\hline $50 \mathrm{mg} \mathrm{L}^{-1}$ salicylic acid & $6.9 \pm 0.12 \mathrm{ab}$ & $4.0 \pm 0.09$ & $88.4 \pm 2.1 \mathrm{ab}$ & $140.0 \pm 2.0 \mathrm{~d}$ \\
\hline $100 \mathrm{mg} \mathrm{L}^{-1}$ acetyl salicylic acid & $6.8 \pm 0.1 \mathrm{ab}$ & $3.9 \pm 0.15$ & $80.0 \pm 1.5 \mathrm{c}$ & $159.6 \pm 1.3 \mathrm{~b}$ \\
\hline $100 \mathrm{mg} \mathrm{L}^{-1}$ ascorbic acid & $6.9 \pm 0.12 \mathrm{ab}$ & $3.9 \pm 0.13$ & $81.8 \pm 2.0 \mathrm{c}$ & $152.6 \pm 2.2 \mathrm{c}$ \\
\hline $10 \%$ Sucrose $+50 \mathrm{mg} \mathrm{L}^{-1}$ salicylic acid & $7.0 \pm 0.08 \mathrm{a}$ & $4.2 \pm 0.07$ & $90.0 \pm 1.1 \mathrm{a}$ & $141.8 \pm 2.2 \mathrm{~d}$ \\
\hline $10 \%$ Sucrose $+100 \mathrm{mg} \mathrm{L}^{-1}$ acetyl salicylic acid & $6.5 \pm 0.08 \mathrm{c}$ & $4.0 \pm 0.08$ & $84.0 \pm 2.2 \mathrm{bc}$ & $162.6 \pm 2.8 \mathrm{~b}$ \\
\hline $10 \%$ Sucrose $+100 \mathrm{mg} \mathrm{L}^{-1}$ ascorbic acid & $6.6 \pm 0.13 \mathrm{bc}$ & $4.0 \pm 0.13$ & $81.6 \pm 1.8 \mathrm{c}$ & $164.2 \pm 2.2 \mathrm{~b}$ \\
\hline Significance $^{\mathrm{w}}$ & $<0.0001$ & NS & $<0.0001$ & $<0.0001$ \\
\hline
\end{tabular}

${ }^{\mathrm{z}}$ Open floret \%age $=\left(\right.$ florets opened/ total florets) $\mathrm{x} 100,{ }^{\mathrm{y}}$ Ion leakage \%age $=\mathrm{EC} 2 / \mathrm{EC} 1 \times 100,{ }^{\mathrm{x}}$ Means separation within column by Least significant difference test at $P \leq 0.05$. ${ }^{\text {w }} \mathrm{P}$ Values were obtained using General Linear Model (GLM) procedures of Statistix 8.1. NS $=$ Non-significant at $P>0.05$. "Values are averages of 30 replicate florets. ${ }^{* *}$ Values are averages of 25 replicate florets.

observed $(\mathrm{P}<0.0001)$ among various pulsing treatments for floret length (Table 2). Longest floret $(7.0 \mathrm{~cm})$ was recorded in spikes pulsed with $10 \%$ sucrose plus $50 \mathrm{mg} \mathrm{L}^{-1}$ salicylic acid which was $0.9 \mathrm{~cm}$ longer than the florets in control $(6.1$ $\mathrm{cm})$. No statistical differences were recorded in the floret lengths of the spikes pulsed with $10 \%$ sucrose plus $50 \mathrm{mg} \mathrm{L}^{-1}$ salicylic acid, $50 \mathrm{mg} \mathrm{L}^{-1}$ salicylic acid, $100 \mathrm{mg} \mathrm{L}^{-1}$ acetyl salicylic acid and $100 \mathrm{mg} \mathrm{L}^{-1}$ ascorbic acid, viz. $7.0 \mathrm{~cm}, 6.9$ $\mathrm{cm}, 6.8 \mathrm{~cm}$ and $6.9 \mathrm{~cm}$, respectively.

Floret head diameter $(\mathrm{cm})$ : Non-significant differences were observed $(\mathrm{P}>0.05)$ among various pulsing treatments for floret diameter (Table 2). However, spikes pulsed with $10 \%$ sucrose plus $50 \mathrm{mg} \mathrm{L}^{-1}$ salicylic acid and $10 \%$ sucrose exhibited numerically greater floret diameter $(4.2 \mathrm{~cm})$ each, while minimum diameter $(3.8 \mathrm{~cm})$ was recorded in control.

Open florets (\%): Highly significant differences were observed $(\mathrm{P}<0.0001)$ among various pulsing treatments for open florets percentage (Table 2). Highest percentage were opened in the spikes (20\%) pulsed with $10 \%$ sucrose plus $50 \mathrm{mg} \mathrm{L}^{-1}$ salicylic acid as compared to control (70\%) which had the minimum open florets percentage.

Ion leakage (\%): Data collected on ion leakage percentage of florets also exhibited highly significant differences $(\mathrm{P}<0.0001)$ among various pulsing treatments. Minimum ion leakage percentage was noted in the florets of spikes pulsed with $50 \mathrm{mg} \mathrm{L}^{-1}$ salicylic acid and combination of $10 \%$ sucrose plus $50 \mathrm{mg} \mathrm{L}^{-1}$ salicylic acid, viz. $140.0 \%$ and $141.8 \%$, respectively. On the other hand, maximum ion leakage percentage was recorded in the florets of spikes in control and pulsed with $10 \%$ sucrose, viz. $175.8 \%$ and $171.8 \%$, respectively (Table 2).

Change in EC $\left(d S m^{-1}\right)$ and $p H$ : Data regarding change in vase water $\mathrm{pH}$ showed variable response. In some treatments it was increased, viz. Control, $10 \%$ Sucrose, $50 \mathrm{mg} \mathrm{L}^{-1}$ salicylic acid, $100 \mathrm{mg} \mathrm{L}^{-1}$ acetyl salicylic acid and $10 \%$ sucrose plus $100 \mathrm{mg} \mathrm{L}^{-1}$ acetyl salicylic acid but in others it 
was decreased. In contrast, EC of all treatment decreased during vase life evaluation period accept in the vase solution containing $50 \mathrm{mg} \mathrm{L}^{-1}$ salicylic acid (Table 3).

Change in total soluble solids (TSS) of florets ( ${ }^{0}$ Brix): Data regarding change in TSS of florets during the vase life period showed variable trend for various pulsing treatments. TSS remained same or slightly increased in the florets of the spikes pulsed with the pulsing treatment having sucrose while decreased with the pulsing without sucrose (Table 3 ).

\section{DISCUSSION}

Largely, from aforementioned results, it is evident that pulsing treatments with various preservative solutions including $10 \%$ sucrose, $50 \mathrm{mg} \mathrm{L}^{-1}$ salicylic acid, $100 \mathrm{mg} \mathrm{L}^{-1}$ acetyl salicylic acid, $100 \mathrm{mg} \mathrm{L}^{-1}$ ascorbic acid, $10 \%$ sucrose plus $50 \mathrm{mg} \mathrm{L}^{-1}$ salicylic acid, $10 \%$ sucrose plus $100 \mathrm{mg} \mathrm{L}^{-1}$ acetyl salicylic acid, $10 \%$ sucrose plus $100 \mathrm{mg} \mathrm{L}^{-1}$ ascorbic acid and distilled water (control) significantly affected spike and floret characteristics of cut tuberose as presented in Table 1. and 2. It was observed that among various pulsing treatments, $10 \%$ sucrose plus $50 \mathrm{mg} \mathrm{L}^{-1}$ salicylic acid for 24 hours reported the longest vase life $(10.2 \mathrm{~d})$, more days to open $50 \%$ florets (5.0 days), maximum dry weight percentage (13.2\%) and the superior quality spikes (7.6) (Table 1) relative to control. Similarly, the longest florets $(7.0 \mathrm{~cm})$, greater floret diameter $(4.2 \mathrm{~cm})$, the highest percentage of opened florets $(90.0 \%)$ and the minimum ion leakage $(140.0 \%)$ was noted in the florets of spikes of cut tuberose pulsed with $10 \%$ sucrose plus $50 \mathrm{mg} \mathrm{L}^{-1}$ salicylic acid for 24 hours period as compared to control (Table 4.5.2). On the other hand, the highest water uptake $(106.0 \mathrm{~mL})$ and the maximum relative fresh weight percentage $(109.9 \%)$ were observed in cut tuberose spikes treated with $50 \mathrm{mg} \mathrm{L}^{-1}$ salicylic acid without sucrose solution compared to control (Table 1).

The best performance of sucrose solution in maintaining and prolonging postharvest life might be attributed to supplementing the natural sugar (Nowak and Rudnicki, 1990), preventing leaf desiccation (Silvanda et al., 2011), improving water balance (Hutchinson et al., 2003) and increased osmotic potential of the stem and petals, thus improving their ability to absorb nutrients and maintain their turgidity (Abbasi and Asil, 2011). Our results are also in lines with Bahrehmand et al. (2014) and Srivastava et al. (2015) for tuberose cut flowers and chrysanthemum, respectively. Moreover, Lama et al. (2013) reported extended vase life in cut roses due to sucrose solution are attributed to provision of carbohydrates and reduction in oxidative stress mediated damages during senescence. Similar results were observed in present study as mentioned in Tables 1 and 2 vis-à-vis various spike and floret characteristics studied. However, sucrose alone was not suitable which may be attributed to probable increase of microbial agents in vase solution. Therefore, combining sucrose with a biocide, changing the vase solution or re-cutting the stem end may reverse this effect (Jowkar and Salehi, 2005).

Exogenously applied SA at pre harvest stage increased flower quality, and vase life of cut rose. These results suggest that SA could be used as potential growth promoter to improve postharvest life of roses (Abdolmaleki, 2015). SA has also been found to play a key role in the regulation of plant growth, development and in responses to environmental stresses (Hayat et al., 2010). Further, its role is evident in ion uptake and transport (Harper and Balke, 1981), photosynthetic rate, stomatal conductance and transpiration (Khan et al., 2003). SA can modulate plant responses to a wide range of oxidative stresses (Shirasu et al., 1997). SA and its derivative, acetyl salicylic acid (ASA) also plays a role as an antagonist to ethylene action have been reported to inhibit ethylene production in pear (Leslie and Romani, 1988) and banana (Srivastava and Dwivedi, 2000). Also, the upward gravitropic bending of snapdragon was inhibited using SA (Friedman et al., 2003).

Similar results were observed in present study in which SA alone or in combination with sucrose helped strengthening various spike (Table 1) and floret (Table 2) characteristics of cut tuberose. Besides, SA modulates plant responses to a wide range of oxidative stresses and prevents cell wall degradation and thereby reduction in water loss (Shirasu et al., 1997). The present study results are also in accordance with the results proposed by Marandi et al. (2011), Kazemi et al. (2011) and Tehranifar et al. (2013) vis-à-vis postharvest life of cut flowers. Therefore, SA is used as a vase solution additive being natural, cheap, safe and biodegradable compound for extending the postharvest longevity of cut flower species susceptible to vascular blockage of bacteria and ethylene (Tehranifar et al., 2013).

\section{CONCLUSION}

It is concluded that pulsing of cut tuberose spikes with $50 \mathrm{mg}$ $\mathrm{L}^{-1} \mathrm{SA}$ with or without $10 \%$ sucrose proved effective for extending vase life and improving postharvest performance of cut tuberose spikes.

\section{REFERENCES}

Abbasi, J. and M.H. Asil. 2011. Study on prolonging the vase life of tuberose cut flowers (Polianthes tuberosa L.). South Western J. Horti. Biol. Environ. 2:157-165.

Abdolmaleki, M., M. Khosh-Khui, S. Eshghi and A. Ramezanian. 2015. Improvement in vaselife of cut rose cv. "Dolce Vita" by pre-harvest foliar application of calcium chloride and salicylic acid. Int. J. Hortic. Sci. Technol. 2:55-66. 
Abdulrahman, Y.A., S.F. Ali and H.S. Faizi. 2012. Effect of sucrose and ascorbic acid concentrations on vase life of snapdragon (Antirrhinum majus L.) cut flowers. Int. J. Pure Appl. Sci. Technol. 13:32-41.

Ahmad, I. 2009. Production potential and postharvest management of cut rose flowers in Punjab (Pakistan). Ph.D. Thesis, Inst. Hort. Sci., University of Agriculture, Faisalabad, Pakistan.

Ahmad, I., D.C. Joyce and J.D. Faragher. 2011. Physical stem-end treatment effects on cut rose and acacia vase life and water relations. Postharvest Biol. Technol. 59:258-264.

Ahsan, M., S. Rehman, A. Younis, A. Riaz, U. Tariq and R. Waqas. 2012. Different strategies to create earliness and enhance quality of tuberose (Polianthes tuberosa L.) cv. Single. Asian J. Pharm. Biol. Res. 2:84-89.

Ashfaq, M., M. Usman and Q. Mohy-ud-din. 2015. Production, management and marketing of cut flowers, $1^{\text {st }}$ Ed. University Press, University of Agriculture, Faisalabad, Pakistan.

Azizi, S., R. Onsinejad and B. Kaviani. 2015. Effect of ascorbic acid on post-harvest vase life of cut Lisianthus (Eustoma grandiflorum L.) flowers. J. Agric. Biol. Sci. 10:417-420.

Bahrehmand, S., J. Razmjoo and H. Farahmand. 2014. Effects of nano-silver and sucrose applications on cut flower longevity and quality of tuberose (Polianthus tuberosa). Int. J. Hort. Sci. Technol. 1:67-77.

Bayleyegn, A., B. Tesfaye and T.S. Workneh. 2012. Effects of pulsing solution, packaging material and passive refrigeration storage system on vase life and quality of cut rose flowers. Afr. J. Biotech. 11:3800-3809.

Bedour, A.A. and A.E. Rawia. 2011. Improving gladiolus growth, flower keeping quality by using some vitamins application. J. Amr. Sci. 7:169-174.

Cheruth A.J. 2009. Changes in non-enzymatic anti oxidation and ajmalicine production in Catharanthus roseus with different soil salinity regimes. Bot. Res. Intl. 2:1-6.

Conklin, P. 2001. Recent advances in the role of biosynthesis of ascorbic acid. Plant Cell Environment 24:383-394.

De Hertogh, A. and M. Le Nord. 1993. The Physiology of Flower Bulbs, p.589-601. Elvish, Sci. Pub. The Netherlands.

Dest, W.M. and K. Guillard. 1987. Nitrogen and phosphorus nutritional influence on bentgrass. J. Amer. Soc. Hort. Sci. 112:769-773.

El-Kobisy, D.S., K.A. Kady, R.A. Hedani and R.A. Agamy. 2012. Response of pea plant (Pisum sativum L.) to treatment with ascorbic acid. Egypt. J. Appl. Sci. 20:3650.

Enyedi, A.J., N. Yalpani, P. Sliverman and I. Raskin. 1992. Signal molecule in systemic plant resistance to pathogens and pests. Cell 70:879-886.
Friedman, H., S. Meir, A.H. Halevy and S. Philosoph-Hadas. 2003. Inhibition of the gravitropic bending response of flowering shoots by salicylic acid. Plant Sci. 165:905911.

Harper, J.R. and N.E. Balke. 1981. Characterization of the inhibition of $\mathrm{K}^{+}$absorption in oats roots by salicylic acid. Plant Physiol. 68:1349-1353.

Hayat, Q., S. Hayat, M. Irfan and A. Ahmad. 2010. Effect of exogenous salicylic acid under changing environment: A review. Environ. Exp. Bot. 68:14-25.

Hayat, S., N.U. Amin, M.A. Khan, T.M.A. Soliman, M. Nan, K. Hayat, I. Ahmad, M.R. Kabir and L. Zhao. 2012. Impact of silver thiosulphate and sucrose solution on the vase life of rose cut flower cv. Cardinal. Adv. Environ. Biol. 6:1643-1649.

He, S.G., D.C. Joyce, D.E. Irving and J.D. Faragher. 2006. Stem end blockage in cut Grevillea 'Crimson Yul-lo' inflorescences. Postharvest Biol. Technol. 41:78-84.

Hussain, A. 1986. Ornamental Horticulture, p.136. ICAR. New Delhi, India.

Hutchinson, M.J., D.K. Chebet and V.E. Emongor. 2003. Effect of accel, sucrose, and silver thiosulphate on water relations and postharvest physiology of cut tuberose flowers. Afr. Crop Sci. 11:279-287.

Ichimura, K., Y. Kawabata, M. Kishimoto, R. Goto, and K. Yamada. 2002. Variation with the cultivar in the vase life of cut rose flowers. Bull. Natl. Inst. Flori. Sci. 2:9-20.

Jowkar, M.M. and H. Salehi. 2005. Effects of different preservative solutions on the vase life of cut tuberose flowers at usual home conditions. Acta Hort. 669:411415.

Joyce, D.C., S.A. Meara, S.E. Hetherington and P. Jones. 2000. Effects of cold storage on cut Grevillea 'Sylvia' inflorescences. Postharvest Biol. Technol. 18:49-56.

Kazemi, M. and A. Ameri. 2012. Postharvest life of cut gerbera flowers as affected by nano-silver and acetylsalicylic acid. Asian J. Biochem. 7:106-111.

Kazemi, M., E. Hadavi and J. Hekmati. 2011. Role of salicylic acid in decreases of membrane senescence in cut carnation flowers. Am. J. Plant Physiol. 6:106-112.

Kim, Y. and J.S. Lee. 2002. Changes in bent neck, water balance and vase life of cut rose cultivars affected by preservative solution. J. Korean Soc. Hort. Sci. 43:201207.

Khan, W., B. Prithviraj and D.L. Smith. 2003. Photosynthetic responses of corn and soybean to foliar application of salicylates. J. Plant Physiol. 160:485-492.

Khan M.A., A. Younis and A. Riaz. 2015. Postharvest treatments for extending the vase life of cut stock (Matthiola incana L.) cv. 'Gold Cut Series'. Agricul. Commun. 3:37-42.

Lama, B., M. Ghosal, S.K. Gupta and P. Mandal. 2013. Assessment of different preservative solutions on vase life of cut roses. J. Ornamental Plants 3:161-170. 
Leslie, C.A. and R.J. Romani. 1988. Inhibition of ethylene biosynthesis by salicylic acid. Plant Physiol. 88:833-837.

Marandi, R.J., A. Hassani, A. Abdollahi and S. Hanafi. 2011. Improvement of the vase life of cut gladiolus flowers by essential oils, salicylic acid and silver thiosulfate. J. Medicinal Plants Res. 5:5039-5043.

Mirjalili, S.A. 2015. Assessment of concurrent of the sucrose and silver nitrate on cut flower of rose (Rosa hybrida cv. 'Red One'). J. Bio. Env. Sci. 6:122-126.

Nowak, J. and R.M. Rudnicki. 1990. Postharvest handling and storage of cut flowers, florist greens and potted plants. Timber Press, Portland.

Sheikh, F., S.H. Neamati, N. Vahdati and A. Dolatkhahi. 2014. Study on effects of ascorbic acid and citric acid on vase life of cut lisianthus (Eustoma grandiflorum) 'Mariachi blue'. J. Ornam. Plant 4:57-64.

Shirasu, K., A. Nakajima, K. Rajshekar, R.A. Dixon and C. Lamb. 1997. Salicylic acid potentiates an agonistdependent gain control that amplifies pathogen signal in the activation of defense mechanism. Plant Cell 9:261270 .

Silvanda, M.S., M.A. Daniely, J.A. Barbosa, E.A. Ricardo and J. LuizMosca. 2011. Effects of sucrose pulsing and silver nitrate on longevity of two cultivars of cut roses. Interamerican Soc. Tropi. Hort. 54:36-38.
Srivastava, M.K. and U.N. Dwivedi. 2000. Delayed ripening of banana fruit by salicylic acid. Plant Sci. 158:87-96.

Srivastava, R., G. Sharma and S. Chand. 2015. Post-harvest life of cut chrysanthemum cultivars in relation to chemicals, wrapping material and storage conditions. J. Hort. 2:1-4.

Steel, R.G.D., T.H. Torrie and D.A. Dicky. 1997. Principles and Procedures of Statistics: A biometric approach, $3^{\text {rd }}$ Ed. McGraw Hill. Inc., N.Y., USA.

Tehranifar, A., N. Vahdati, Y. Selahvarzi and H. Bayat. 2013. Treatment with salicylic acid extends the vase life of important commercial cut flowers. Adv. Crop Sci. 13:405-413.

Usman, M. and M. Ashfaq. 2013. Economic analysis of tuberose production in Punjab, Pakistan. Sarhad J. Agric. 29:279-283.

van Doorn, W.G., Y. Zagory, Y. de Witte and H. Harkema. 1991. Effects of vase water bacteria on the senescence of cut carnation flowers. Postharvest Biol. Technol. 1:161168.

Woodson, W.P. 1987. Postharvest handling of Bud-cut Freesia flowers. HortScience 22:456-458.

Younis, A., M.A. Khan and M.A. Pervez. 2006. Effect of different chemicals on the vase life of cut rose flowers. Caderno de Pesquisa J. 18:17-27. 